\title{
Cretaceous-Paleogene Transition of Reptilian Tetrapods across Deccan Volcanism in India
}

\author{
Dhananjay M. Mohabey*, Bandana Samant \\ Department of Geology, RTM Nagpur University, Nagpur, India \\ Email: *dinomohabey@yahoo.com
}

How to cite this paper: Mohabey, D.M. and Samant, B. (2019) Cretaceous-Paleogene Transition of Reptilian Tetrapods across Deccan Volcanism in India. Open Journal of Geology, 9, 639-642. https://doi.org/10.4236/ojg.2019.910062

Received: August 16, 2019

Accepted: September 21, 2019

Published: September 24, 2019

Copyright $\odot 2019$ by author(s) and Scientific Research Publishing Inc. This work is licensed under the Creative Commons Attribution International License (CC BY 4.0).

http://creativecommons.org/licenses/by/4.0/ (c) (i) Open Access

\begin{abstract}
Eruptions of lava flows of Deccan large igneous province straddled the Cretaceous-Palaeogene boundary (K-Pg). Sediments associated at different stratigraphic levels within the lava piles of Deccan volcanic sequences (DVS) are mainly terrestrial. We studied the sediments of Eastern and Central Deccan Volcanic Province, and the Malwa Plateau for tracking changes in reptilian tetrapods across the volcanism. The reptiles are mainly represented by abelisaurid-titanosaurid dinosaurs, Alethinophidia madtsoiia snakes, Notosuchian crocodylomorph Simosuchus, bothremydid Kurmademydinae turtles and Anguimorph and Scincomorphs lizards. The evidences suggest that the non-avian dinosaurs were adversely affected by the arrival of the first volcanic flows locally in the province either within C30N or C29R Maastrichtian. The abelisaurid theropods became extinct whereas a single or two species of titanosauriforme dinosaurs survived but eventually became extinct at least $350 \mathrm{ky}$ before the K-Pg boundary with increasing volcanism. The madtsooid snakes and crocodylimorphs were also adversely affected with decline in their diversity and abundance, whereas the Bothremydid turtles survived the initial onslaught of Deccan volcanism and continued across the K-Pg boundary.
\end{abstract}

\section{Keywords}

Deccan Volcanism, Maastrichtian-Paleocene, Reptiles, Extinction

\section{Introduction}

Deccan Large Igneous Province (DLIP) is designated [1] as Western Deccan Volcanic Province (WDVP), Central Deccan Volcanic Province (CDVP), Eastern Deccan Volcanic Province (EDVP), Malwa Plateau and undesignated sequences of Saurastra and Kutch (Figure 1). The different provinces have separate sites, source, timing and duration of eruptions [2]. Erupting in at least three 


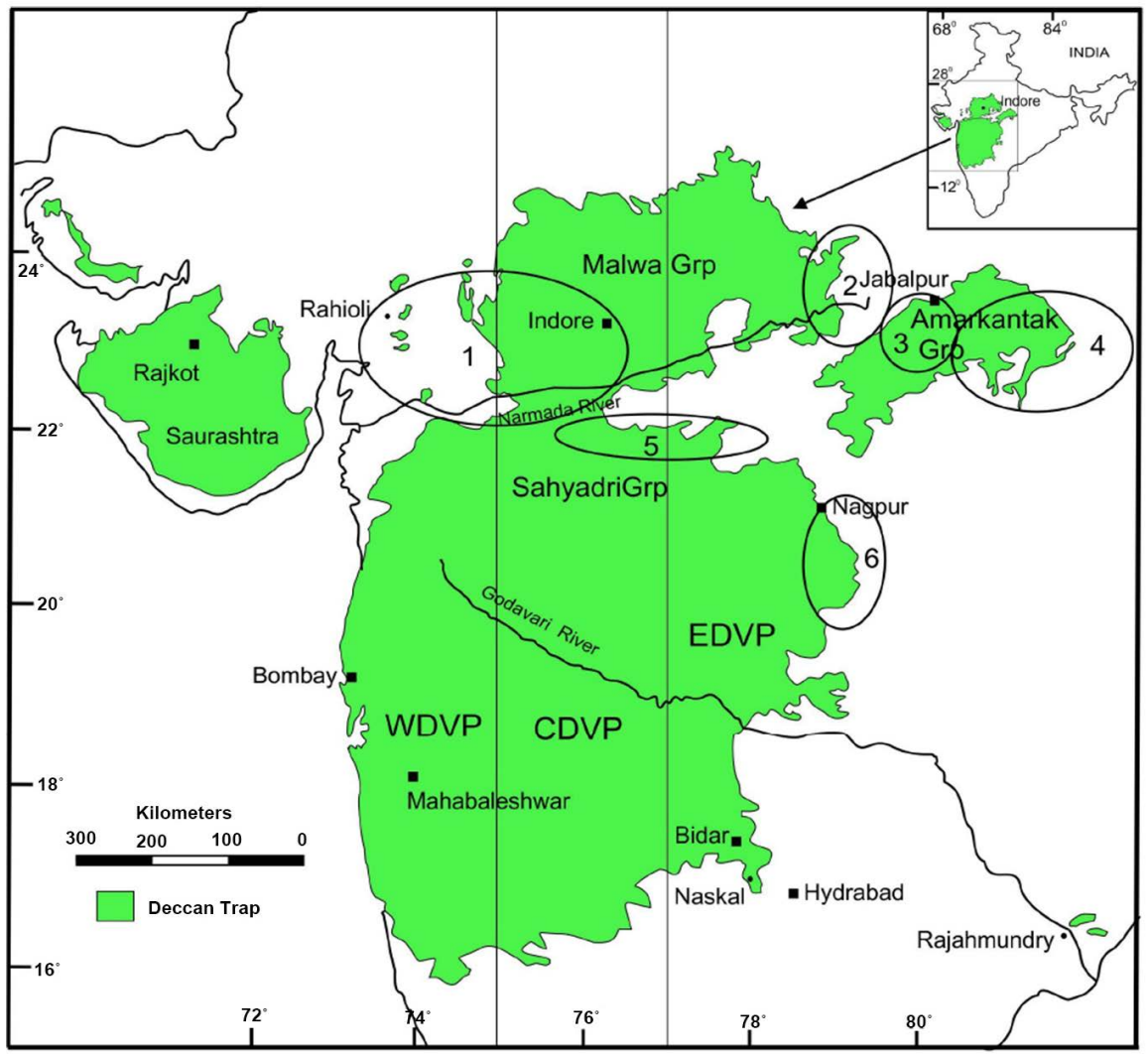

Figure 1. Map showing Deccan Volcanic Provinces in India [4]. 1-6, Lameta (Maastrichtian) inland basins. 1, Balasinor-Jhabua. 2, Sagar. 3, Jabalpur. 4, Ambikapur-Amarkantak. 5, Salburdi. 6, Nand-Dongargaon.

phases across the K-Pg boundary the total duration of Deccan volcanism is debatable [3] but currently considered to have spanned between $68-62.5 \mathrm{Ma}$ ago. The study of lava piles associated with multiple sedimentary deposits is critical for tracking biotic and environmental changes across the volcanism.

\section{Geological Setting}

Deposits associated with Deccan volcanic sequences are designated as "Lameta Formation or infratrappean" deposited before the first lava flows and as "intertrappean" deposited between lava flows during the period of quiescence. Deposited in different inland basins [4] (Figure 1) under alluvial-limnic environments under semi-arid conditions the sediments are main fossiliferous horizons for the Maastrichtian reptiles. The Lameta Formation is of C30N-C29R Maastrichtian age. The intertrappean lake deposits are developed over the fresh lava surface at multiple stratigraphic levels under fluctuating climatic conditions from semi-arid to humid during Deccan transition. Relatively, reptilian fauna in intertrappean sediments is less commonly recorded.

\section{Reptilian Fauna from Indian Maastrichtian-Paleocene}

The reptilian fauna includes two sauropods (Isisaurus colberti and Jainosaurus 
septentrionalis), four medium to large bodied abelisaurid theropods (Indosuchus raptorius, Indosaurus matleyi, Rajasaurus narmadensis, Rahiolisaurus gujaratensis) and three small bodied theropods (Laevisuchus indicus, Jubbulpuria tenius, Composuchus solus). A large number of nest-sites of titanosuriforme dinosaurs with megaloolithid eggs and of abelisaurid theropods with elongatoolithid eggs are known from the Lameta sediments. The dinosaur eggshells are only recovered as small fragments on wet-screening of the sediments, excepting a latest sole find of a single Megaloolithus egg from Teegaon in Madhya Pradesh on Nagpur-Betul road.

The non-dinosaurian reptiles are mainly represented by associated bones of 1 ) turtles-Shweboemys/Bothremydid/Kurmademydinae (Sankuchemys and Kuramademys). 2) Notosuchian crocodylomorph Simosuchus. (3) Althenophidian madtsoiid snakes-Sanajeh indicus, Madtsoiia pisdurensis [5] [6] from Lameta sediments. The Scincomorph and Anguimorph lizards are recorded mainly from intertrappean sediments of both C30N and C29R Maastrichtian.

\section{Conclusion}

The impact of Deccan volcanism on terrestrial reptiles and plants preceded the K-Pg boundary. The titanosaurid and abelisaurid dinosaurs became extinct at least 350 ky before the global K-Pg mass extinction and the abelisaurids were the first to disappear from the Greater India. Titanosaurid and abelisaurid dinosaurs, turtles, Alethinophidia madtsoiia snakes and crocodylomorph Simosuchus were diversified and well established during C30N-C29R before the first Deccan flows. A change in dinosaur fauna from $\mathrm{C} 30 \mathrm{~N}$ was found in Kheda region in western India, N-D basin in Central India and Malwa Plateau to C29R in the Jabalpur region. The diversity and abundance rapidly declined with the arrival of the first volcanic flows in the region and only titanosaurids with decreased diversity and much reduced abundance could survive the initial onslaught of the volcanism. Anguimorph and Scincomorphs lizards are indicated to have better flourished after the initiation of Deccan eruptions during Maastrichtian (C30N-C29R). The record of reptiles from the Indian Paleocene sediments associated with DVA is almost absent but it could be owing to inadequate sampling.

\section{Acknowledgements}

Authors express thank to Geological Survey of India for facilitating research work and to Anup Dhabale and Deepesh Kumar of RTM Nagpur University for field assistance and to Ministry of Earth Sciences (Grant MoES/PO(GEOSCI)/49/2015). This is a contribution to UNESCO/IUGS/IGCP 679 project.

\section{Conflicts of Interest}

The authors declare no conflicts of interest regarding the publication of this paper. 


\section{References}

[1] Deshmukh, S.S., Sano, T., Fuji, T., Nair, K.K.K., Yedekar, D.B., Umino, S., Iwamori, H. and Aramaki, S. (1996) Chemical Stratigraphy and Geochemistry of the Basalt Flows from the Central and Eastern Parts of Deccan Volcanic Province of India. Gondwana Geological Magazine, Special Publication, 2, 145-170.

[2] Mohabey, D.M. and Samant, B. (2013) Deccan Continental Flood Basalt Eruption Terminated Indian Dinosaurs before the Cretaceous-Paleogene Boundary. Geological Society of India, Special Publication, 1, 260-267.

[3] Sprain, C.J., Renne, P.R., Vanderkluysen, L., Pande, K., Self, S. and Mittal, T. (2019) The Eruptive Tempo of Deccan Volcanism in Relation to the Cretaceous-Paleogene Boundary. Science, 363, 866-870. https://doi.org/10.1126/science.aav1446

[4] Mohabey, D.M. (1996) Nand-Dongargaon Inland Basin, Maharashtra: The Fossil and Lithological Evidences. Memoir Geological Society of India, 37, 363-386.

[5] Wilson, J.A., Mohabey, D.M., Peter, S.E. and Head, J.J. (2010) Predation upon Hatchling Dinosaurs by a New Snake from the Late Cretaceous of India. PLoS Biology, 8, e1000322. https://doi.org/10.1371/journal.pbio.1000322

[6] Mohabey, D.M., Head, J.J. and Wilson, J.A. (2011) A New Species of the Snake Madtsoia from the Upper Cretaceous of India and Its Paleobiogeographic Implications. Journal of Vertebrate Paleontology, 31, 588-595.

https://doi.org/10.1080/02724634.2011.560220 